\title{
INSTRUMENTO DE LEGITIMAÇÃO FUNDIÁRIA E INCONSTITUCIONALIDADE PARCIALSEM REDUÇÃO DE TEXTO
}

\author{
Instrument of landholding legitimation and partial \\ unconstitutionality without curtailment of text
}

\section{Alexandre Prevedello}

Mestre em Direito pela Fundação Escola Superior do Ministério Público do Rio Grande do Sul (2018). Especialista em Direito Constitucional pela Universidade do Sul de Santa Catarina (2009). Especialista em Processo Civil pela Universidade Federal do Rio Grande do Sul (2008). Graduado em Direito pela Pontifícia Universidade Católica do Rio Grande do Sul (2004). Assessor de Desembargador no Tribunal de Justiça do Estado do Rio Grande do Sul.

\section{Resumo}

Este ensaio investiga, mediante uma abordagem dedutiva, o instrumento de legitimação fundiária introduzido pela Lei 13.465/2017, que se consubstancia em uma nova forma originária de aquisição do direito real de propriedade, inclusive sobre áreas públicas. Examina-se o novo instrumento de regularização fundiária urbana, que é objeto de questionamentos quanto à sua constitucionalidade, na perspectiva de sua manutenção no sistema jurídico nacional. Nesse sentido, advoga-se a necessidade de o Supremo Tribunal Federal aplicar a técnica da jurisdição constitucional de declaração de inconstitucionalidade parcial sem redução de texto para fins de afastar a Regularização Fundiária Urbana de Interesse Específico (Reurb-E) do seu escopo normativo, mantendo-se sua aplicabilidade exclusivamente para a modalidade de Regularização Fundiária Urbana de Interesse Social (Reurb-S).

Palavras-chave: Direito à moradia. Regularização fundiária. Legitimação fundiária. Inconstitucionalidade parcial sem redução de texto.

\begin{abstract}
The essay investigates, by a deductive approach, the instrument of landholding legitimation introduced by the act no. $13.465 / 2017$, that consist in a new original form of property law right of acquisition, on public areas as also. It is examined the new instrument of urban landholding legitimation, that is object of countless questionings regards its constitutionality, in the perspective of its conservation in the national juridical system. In that way, it's advocated the need that the Federal Supreme Court applies the technique of the constitutional jurisdiction of partial declaration of unconstitutionality without curtailment of text for that it can end the Urban Landholding Regularization of Specific Interest (Reurb-E) of its normative mark, keeping its applicability exclusively to the method of Urban Landholding Regularization of Social Interest (Reurb-S).
\end{abstract}

Keywords: Housing Rights. Landholding Regularization. Landholding Legitimation. Partial Unconstitutionality Without Curtailment of Text.

\section{Sumário}

1. Introdução; 2. Regularização fundiária urbana na Lei 13.465/2017; 3. Instrumento de legitimação fundiária; 4. Questionamentos acerca da constitucionalidade da legitimação fundiária; 5. Legitimação fundiária e inconstitucionalidade parcial sem redução de texto; 6 . Considerações finais; 7. Notas; Referências 


\section{INTRODUÇÃO}

A política de planejamento e desenvolvimento urbano com ênfase na função social da propriedade e da cidade é produto dos debates ocorridos durante o processo de redemocratização do Estado brasileiro. As disposições constitucionais (arts. 182 e 183) elaboradas pelo poder constituinte originário impõem a criação e a aplicação de políticas públicas concernentes à regularização fundiária urbana para fins de moradia digna, além de outros objetivos como a segurança, a redução das desigualdades sociais, a defesa do meio ambiente e o transporte adequado. Para reforçar a importância destas políticas públicas, a Emenda Constitucional 26/2000 acrescentou ao art. $6^{\circ}$ da CF o direito à moradia como um direito social fundamental.

Entretanto, somente com a promulgação do Estatuto da Cidade (Lei 12.257/2001) houve a positivação de normas infraconstitucionais e a instituição de instrumentos jurídicos capazes de concretizar a função social da propriedade e da cidade em relação aos imóveis urbanos em situação irregular. Com esse mesmo objetivo pode-se apontar ainda a edição da Medida Provisória 2.220/01 (concessão de uso especial de que trata o $\S 1^{\circ}$ do art. 183 da CF) e as Leis 11.124/2005 (sistema nacional de habitação de interesse social - SNHIS) e 11.977/09 (regularização fundiária de interesse social de assentamentos urbanos).

Busca-se com esse aparato normativo regularizar a ocupação desordenada do solo urbano, um problema comum a todas as cidades brasileiras, especialmente nas de maior envergadura. Com isso pretende-se inserir a cidade informal (como as favelas, por exemplo) na cidade formal, quer dizer, naquela em que todos ou a grande maioria dos regulamentos de urbanização são observados, medida imprescindível para a concretização plena da cidadania.

Nesse contexto, a edição da Medida Provisória n. 759/2016, convertida na Lei $13.465 / 2017$, tem sido objeto de questionamento por alguns setores representativos da sociedade (Procuradoria Geral da República, Partido dos Trabalhadores e Instituto dos Arquitetos do Brasil). Isso porque, no entender destes setores, foram introduzidas alterações significativas no sistema normativo sem que elas tenham sido efetivamente debatidas no âmbito da sociedade e também do parlamento.

Não se pretende examinar todos os reflexos jurídicos e as consequências práticas que decorrem da Lei 13.465/2017, tampouco confrontar a integralidade de suas disposições com as normas jurídicas (princípios e regras) constantes na Constituição Federal e no Estatuto da Cidade. O objetivo do estudo é analisar uma questão pontual que emerge do regulamento concernente a um dos novos instrumentos da regularização fundiária urbana (Reurb): a legitimação fundiária.

Nos termos do art. $9^{\circ}$ da Lei $13.465 / 2017$, a regularização fundiária urbana (Reurb) "abrange medidas jurídicas, urbanísticas, ambientais e sociais destinadas à incorporação dos núcleos urbanos informais ao ordenamento territorial urbano e à titulação de seus ocupantes". Por sua vez, a legitimação fundiária "constitui forma originária de aquisição do direito real de propriedade conferido por ato do Poder Público, exclusivamente no âmbito da Reurb, àquele que detiver em área pública ou possuir em área privada, como sua, unidade 
imobiliária com destinação urbana, integrante de núcleo urbano informal consolidado existente em 22 de dezembro de 2016" (art. 23 do mesmo regramento legal).

Para tanto, examina-se, controverte-se e propõe-se uma solução jurídica para lidar com a entendida como indevida diferenciação realizada na lei quanto ao requisito de que apenas o beneficiário da Reurb-S (Regularização Fundiária Urbana de Interesse Social, que engloba a população de baixa renda) não seja concessionário, foreiro ou proprietário de imóvel urbano ou rural (art. $23, \S 1^{\circ}$ ) para fins de acesso ao novo instrumento jurídico. Isso tudo partindo do pressuposto de que o instituto jurídico será mantido no ordenamento jurídico nacional.

O desenvolvimento do trabalho ocorrerá em quatro etapas. Primeiro, faz-se um breve exame das inovações e modificações inseridas no âmbito da regularização fundiária urbana pela Lei 13.465/2017. Depois, analisa-se o instrumento de legitimação fundiária urbana e questiona-se sua constitucionalidade, enfatizando a existência de critérios restritivos para sua utilização apenas em se tratando da Reurb-S. Por fim, busca-se oferecer, mediante o exame das técnicas de decisões na jurisdição constitucional, uma solução jurídica adequada ao tema.

\section{REGULARIZAÇÃO FUNDIÁRIA URBANA NA LEI 13.465/2017}

A Medida Provisória 759, de dezembro de 2016, posteriormente convertida na Lei 13.465, de julho de 2017, positivou inovações relevantes em relação às políticas públicas de regularização fundiária urbana, como a legitimação fundiária, a institucionalização do direito real de laje, ${ }^{1}$ além de alterar inúmeras leis concernentes ao seu âmbito de atuação. ${ }^{2}$ As novas disposições ensejaram algumas controvérsias, inclusive quanto à sua compatibilidade com a Constituição Federal, de modo que há três ações diretas de inconstitucionalidade tramitando no Supremo Tribunal Federal. ${ }^{3}$

No tocante à regularização fundiária urbana (Reurb) a disciplina foi praticamente completa, na medida em que foi regulada a legitimidade, foram enumerados os instrumentos jurídicos passíveis de utilização, bem como disciplinada a demarcação urbanística e os procedimentos administrativos, inclusive no tocante aos registros públicos.

Logo, a Lei 13.465/2017 introduziu "um detalhado, sofisticado e inovador plexo de normas e institutos jurídicos" (MAFFINI, 2017, p. 565) quanto ao tema, cuja complexidade é demonstrada pelo conceito de regularização fundiária - que não significa apenas proteger juridicamente a posse sobre determinado imóvel assinalando título de propriedade ou direito real -, a saber:

\footnotetext{
Regularização fundiária é um processo conduzido em parceria pelo Poder Público e população beneficiária, envolvendo as dimensões jurídica, urbanística e social de uma intervenção que, prioritariamente, objetiva legalizar a permanência de moradores de áreas urbanas ocupadas irregularmente para fins de moradia e, acessoriamente, promove melhorias no ambiente urbano e na qualidade de vida do assentamento, bem como incentiva o pleno exercício da cidadania pela comunidade sujeito do projeto. (ALFONSIN, 2007, p. 78).
}

Por ser um processo complexo, as normas gerais e procedimentos concernentes à Regularização Fundiária Urbana (Reurb) abrangem, nos termos do art. 9, "medidas jurí- 
dicas, urbanísticas, ambientais e sociais destinadas à incorporação dos núcleos urbanos informais ao ordenamento territorial urbano e à titulação de seus ocupantes."

Não obstante, a nova legislação priorizou a regularização dos núcleos urbanos informais através da concessão de titulação jurídica aos seus ocupantes. Isso se deu em razão do aumento de instrumentos e de legitimados para postulação da titulação, acrescendo maiores possibilidades de êxito na regularização fundiária e no acesso ao sistema registral oficial do ordenamento brasileiro (CARMONA et al, 2018, p. 35).

Um núcleo urbano informal é, nos termos do art. 11, II, "aquele clandestino, irregular ou no qual não foi possível realizar, por qualquer modo, a titulação de seus ocupantes, ainda que atendida a legislação vigente à época de sua implantação ou regularização." Por sua vez, o ocupante é definido como "aquele que mantém poder de fato sobre lote ou fração ideal de terras públicas ou privadas em núcleos urbanos informais." (art. 11, VIII).

Os legitimados para requererem a regularização encontram-se no art. 14: entes da federação, inclusive as entidades da administração pública indireta; os beneficiários, individual ou coletivamente, e as associações, organizações sociais e outras entidades que exerçam atividades no tocante à matéria; bem como os proprietários de imóveis ou de terrenos (inclusive loteadores ou incorporadores ${ }^{4}$ ), a Defensoria Pública e o Ministério Público.

Os institutos jurídicos da regularização fundiária foram referidos no art. 15: legitimação fundiária, legitimação de posse, usucapião, desapropriação em favor dos possuidores, arrecadação do bem vago, consórcio imobiliário, desapropriação por interesse social, direito de preempção, transferência do direito de construir; requisição, em caso de perigo público iminente; intervenção do Poder Público em parcelamento clandestino ou irregular; alienação do imóvel pela administração pública diretamente para seu detentor; concessão de uso especial para fins de moradia; concessão de direito real de uso; e doação e compra e venda.

Daí a razão de se considerar a "maior iniciativa legislativa acerca do assunto, da qual se espera que possa contribuir para a redução do imenso passivo fundiário urbano brasileiro." (CARMONA et al, 2018, p. 34).

Ao abordar a evolução da regularização fundiária urbana no ordenamento jurídico nacional, Scheid (2017, p. 450) afirma que as controvérsias acerca da nova legislação não impedem que se verifique uma evolução legislativa sobre o tema em compasso com o princípio da função social da propriedade. Isso porque "desde o momento em que o proprietário deixa de preencher a sua função social, a coletividade está naturalmente autorizada a intervir para assegurar uma exploração indispensável à vida coletiva."

Ao presente estudo é relevante ainda destacar e diferenciar as duas modalidades constantes na Lei $13.465 / 2017$, as quais serão confrontadas quando do exame das propriedades e requisitos da legitimação fundiária: a Regularização Fundiária Urbana de Interesse Social (Reurb-S) e a Regularização Fundiária Urbana de Interesse Específico (Reurb-E).

A Reurb-S é aquela "aplicável aos núcleos urbanos informais ocupados predominantemente por população de baixa renda, assim declarados em ato do Poder Executivo municipal” (art. 13, I), enquanto a Reurb-E aplica-se às hipóteses não qualificadas como Reurb-S 
(art. 13, II), ou seja, para todos os demais casos que não envolvem população de baixa renda.

\title{
3. INSTRUMENTO DA LEGITIMAÇÃO FUNDIÁRIA
}

O instrumento de legitimação fundiária ${ }^{5}$ é uma relevante novidade inserida no ordenamento jurídico. Constitui, nos termos do art. 23:

\begin{abstract}
forma originária de aquisição do direito real de propriedade conferido por ato do Poder Público, exclusivamente no âmbito da Reurb, àquele que detiver em área pública ou possuir em área privada, como sua, unidade imobiliária com destinação urbana, integrante de núcleo urbano informal consolidado existente em 22 de dezembro de 2016.
\end{abstract}

É, portanto, uma nova forma originária de aquisição do direito real de propriedade, inclusive sobre áreas públicas, desde que o beneficiário seja integrante de núcleo urbano informal consolidado 6 e comprovadamente existente na data de 22/12/2016 (art. $9^{\circ}$, §2 $2^{\circ}$ ). Objetiva regularizar situações informais já consolidadas quando da edição da Medida Provisória 759/2016, não sendo aplicável para situações futuras. É importante assinalar que não há requisitos concernentes às dimensões do imóvel e de tempo da posse ou detenção.

A estrutura jurídica da legitimação fundiária concernente à aquisição e perda da propriedade imóvel, em se tratando de particulares, não é novidade no ordenamento jurídico, pois se assemelha a outros institutos previstos na Constituição Federal, como a usucapião e a desapropriação. Há pontos em comum com a usucapião caso se entenda que a legitimação fundiária versa sobre um ato administrativo vinculado, enquanto prepondera a aproximação com a desapropriação indireta caso ela seja compreendida como ato discricionário e expropriatório7 (REIS; LELIS, 2018, p. 53-55).

Alguns autores têm se inclinado em reconhecer a discricionariedade do ato, ${ }^{8}$ ainda que não haja tal indicação legal. Nesses moldes, o direito subjetivo do ocupante é referente somente ao pedido de processamento da regularização fundiária nos aspectos admitidos pela legislação. Isso significa que o Município poderá escolher entre os diferentes instrumentos para fins de regularização fundiária, quer dizer, "haverá um juízo de conveniência e oportunidade do Município na eleição do instrumento, diversamente da instauração do procedimento, que é exigível pelos requerentes sem que tal juízo possa ser feito." (REIS; LELIS, 2008, p. 55).

Assim, em se tratando de legitimação fundiária em área privada resultante de ato administrativo discricionário, a natureza jurídica é de expropriação. Ao fim do procedimento da Reurb se extingue a propriedade para um e se outorga a outro, sem indenização ao expropriado. Tal circunstância qualifica a legitimação fundiária como um confisco de bem vedado pelo art. $5^{\circ}, \mathrm{XXIV}$, da $\mathrm{CF} / 88$, ainda que útil à sua finalidade de regularização fundiária (REIS; LELIS, 2008, p. 57).

Por outro lado, a legitimação fundiária de área pública (art. 23, $§ 4^{\circ}$, da Lei $13.465 / 2017^{9}$ ) também padece de vícios que afetam ou dificultam sua manutenção no sistema jurídico. Se a transferência do bem público ao particular decorre de ato discricionário, a legitimação fundiária se torna mais uma via para a titulação do beneficiário que se junta à compra e venda, doação e outras, mas com um problema que decorre do disposto no art. 71 do mesmo 
diploma legal. ${ }^{10} \mathrm{Se} o$ ato administrativo for vinculado, ter-se-á uma hipótese de usucapião de bem público, afrontando o art. 183 da CF. (REIS; LELIS, 2018, p. 58-59).

A primeira hipótese, embora mais adequada à formatação do instituto, pode ser utilizada como um instrumento para fins de arbitrariedade e também de desvios de finalidade ao afastar a participação democrática do procedimento (art. 71). Inclusive pode servir de incentivo a patologias corruptivas já conhecidas no âmbito da execução de políticas públicas.

É importante registrar que o instrumento tem a capacidade de promover, mediante ato administrativo, a entrega do direito de propriedade da unidade imobiliária ao ocupante e seus "efeitos na pós-titulação não serão discrepantes daqueles produzidos nos casos de doação e compra e venda em que há transferência da propriedade." (CARMONA et al, 2018, p. 36). O resultado disso é a possibilidade de transação do direito que foi objeto de regularização fundiária. ${ }^{11}$

Essa permissão encontra referência expressa no art. $23, \S 2^{\circ}$, ou seja, a legitimação fundiária acarreta a aquisição da unidade "com destinação urbana livre e desembaraçada de quaisquer ônus, direitos reais, gravames ou inscrições, eventualmente existentes em sua matrícula de origem, exceto quando disserem respeito ao próprio legitimado."12

Por fim, a legislação dispôs (art. 23, caput e $\S \S 1^{\circ}$ e $2^{\circ}$ ) que a legitimação fundiária se aplica tanto aos casos de Reurb-S (núcleos urbanos informais ocupados predominantemente por população de baixa renda) como às hipóteses de Reurb-E (demais núcleos urbanos informais). Foram inseridos condicionantes ou requisitos para a Reurb-S (art. $23, \S 1^{\circ}$ ), sendo relevante a previsão (inciso I) de que o beneficiário não pode ser concessionário, foreiro ou proprietário de imóvel urbano ou rural.

Trata-se de uma condição que não reflete qualquer impropriedade se examinada isoladamente, até porque é uma disciplina usual no âmbito da regularização fundiária. O problema não é sua previsão para a Reurb-S, mas a omissão de semelhante previsão para a Reurb-E, que, dessa forma, não possui qualquer condicionante.

Essa falta (ou falha) de isonomia e suas possíveis soluções jurídicas serão objeto de exame posterior; antes, no entanto, é necessário examinar o conteúdo e a extensão das ações de inconstitucionalidade apresentadas para verificar se tal particularidade foi objeto de insurgência junto ao Supremo Tribunal Federal.

\section{QUESTIONAMENTOS ACERCA DA CONSTITUCIONALIDADE DA LEGITIMAÇÃO FUNDIÁRIA}

Foram apresentadas três ações diretas de inconstitucionalidade em face da Lei 13.465/2017. Na primeira (ADI 5.771) houve requerimento de inconstitucionalidade de sua integralidade; a segunda (ADI 5.883) versa sobre inúmeras disposições, inclusive quanto à regularização fundiária; a terceira (ADI 5.787) trata exclusivamente da regularização fundiária urbana.

O argumento principal da ADI n. 5. 771 pela inconstitucionalidade da legitimação fundiária refere-se à inexistência de tempo mínimo de ocupação ou vinculação de seu uso à 
moradia, premiando e incentivando ocupações clandestinas e ilícitas, além dos falsificadores de títulos - denominados "grileiros". Além disso, afirma-se a contrariedade em relação a disposições constitucionais que exigem tempo mínimo de posse (usucapião especial urbano e rural). Não houve questionamento quanto à previsão de requisitos restritivos exclusivamente para a Reurb-S.

$\mathrm{Na}$ ADI 5.787 houve requerimento para que todos os dispositivos concernentes à legitimação fundiária sejam declarados inconstitucionais por afronta aos arts. $5^{\circ}, \mathrm{XXIII}, 182, \S 2^{\circ}$, e 183, caput e $\S 3^{\circ}$, da CF/88. O problema ora examinado foi mencionado como inconstitucional por estabelecer apenas para a Reurb-S "diversos requisitos que devem ser cumpridos, ao passo que, para a alta renda, o critério é discricionário do Poder Público, sem qualquer amarra legal. Tal previsão fere de morte o princípio da isonomia, previsto constitucionalmente". Questionou-se ainda a falta de lapso temporal para comprovação do animus domini, apontando-se que o critério único de ocupação em 22 de dezembro de 2016 desrespeita todos os preceitos constitucionais e infraconstitucionais correspondentes ao direito à moradia e à função social da propriedade via regularização fundiária.

Na ADI 5.883 afirma-se que a legitimação fundiária afronta diretamente a proteção constitucional da propriedade prevista no art. $5^{\circ}$, XXII (direito de propriedade); art. $5^{\circ}$, XXIII (função social da propriedade); art. 5, XIV (desapropriação mediante indenização); art. $5^{\circ}$, LIV (devido processo legal); art. 23, I (competência comum de conservação do patrimônio público); art. 170, II e III (propriedade privada e função social da propriedade como princípios da ordem econômica); art. 182, §4 , III (desapropriação sanção mediante indenização); e art. $183, \S 3^{\circ}$ (interdição de aquisição de imóveis públicos por usucapião).

Quanto à diferenciação entre Reurb-S e Reurb-E, foi mencionado que nos casos de Reurb-E não está caracterizado interesse social, circunstância que exigiria a imposição de condições específicas e mais limitadoras, bem como restrições no tocante aos instrumentos cabíveis. Enfatizou-se que foi exatamente o contrário que ocorreu, na medida em que foram estabelecidas exigências (art. $23, \S 1^{\circ}$ ) apenas para a Reurb-S, facilitando sobremaneira a transferência de terras, inclusive públicas, a pessoas de média e alta renda. A conclusão foi de tratamento desigual em desfavor das pessoas de baixa renda, razão pela qual é possível denominar a norma como Lei da Grilagem, já que um de seus maiores potenciais é o de premiar e estimular a ação de grileiros.

A síntese dos principais fundamentos das ações no tocante ao instituto da legitimação fundiária demonstram a sua fragilidade jurídica se adequadamente confrontada às normas constantes da Constituição Federal e aos próprios objetivos da política pública de regularização fundiária urbana. Por outro lado, incumbe à dogmática jurídica, na eventualidade de sua manutenção no ordenamento jurídico nacional, ou enquanto se aguarda o julgamento das ações, formular soluções para que a sua aplicação não seja instrumento jurídico capaz de fomentar ainda mais a desigualdade social. 


\title{
5. LEGITIMAÇÃO FUNDIÁRIA E INCONSTITUCIONALIDADE PARCIAL SEM REDUÇÃO DE TEXTO
}

A partir das considerações anteriores ficou evidenciado que a legislação inverteu os objetivos principais da política urbana ao condicionar para a população menos favorecida a prova da inexistência de algum direito de propriedade em relação a imóvel urbano ou rural, mesmo que de pequeno valor, e tornar incondicionado para as faixas de maior renda.

Assim, um grande proprietário de terras ou de imóveis urbanos pode ter acesso ilimitado ao instrumento criado pela Lei $13.465 / 2017$, inclusive sem condicionante quanto ao tempo de posse ou das dimensões da unidade. Tal circunstância permite a concentração de propriedades e a especulação imobiliária por um instrumento que deveria ter por escopo exatamente o contrário: garantir o direito à moradia digna pela população econômica e socialmente desfavorecida.

Trata-se de inequívoca afronta a princípios jurídicos "que pautam a regularização fundiária urbana, como a dignidade humana, o direito social à moradia, a função social da propriedade urbana e a distribuição equitativa dos ônus e benefícios urbanos." (REIS; LELIS, 2018, p. 51).

Uma solução é considerar que a legitimação fundiária constitui instrumento exclusivo da Reurb-S. Por oportuno:

\begin{abstract}
Portanto o entendimento que nos parece mais conforme (ou menos desconforme) a tais princípios é que a legitimação fundiária se aplica exclusivamente à Reurb-S, e que as 'modalidades aludidas' no $\S 2^{\circ}$ do art. 23 não são Reurb-S ou Reurb-E, mas sim Reurb em imóveis públicos ou em imóveis privados. Outro elemento a contribuir para tal conclusão é que o $\S 4^{\circ}$ do art. 23 prescreve que os entes políticos poderão reconhecer o direito de propriedade aos ocupantes do núcleo urbano informal regularizado por meio da legitimação, "na Reurb-S de imóveis públicos". Neste caso, como a lei limita expressamente a possibilidade de legitimação fundiária de imóveis públicos à Reurb-S, seria contraditório e desarrazoado entender que o instrumento se aplicaria à Reurb-E apenas em se tratando de imóveis privados. Assim sendo, nos parece mais coerente com os princípios que orientam a regularização fundiária concluir que a legitimação fundiária é mesmo um instrumento aplicável apenas à Reurb-S. (REIS; LELIS, 2018, p. 51).
\end{abstract}

No mesmo sentido, Godoy (2017, p. 467) afirma que "apenas na Regularização Fundiária Urbana de Interesse Social a legitimação fundiária poderá ser concedida", embora não problematize a questão à luz da redação do texto legislativo. Do mesmo modo, Maffini (2017, p. 567) afirma que a legitimação fundiária é instituto específico da Reurb-S, como indica o $\S 1^{\circ}$ do art. 23.

Tais soluções não se revelam juridicamente adequadas porque olvidam o sentido unívoco que decorre do texto constante do caput e também dos $\S \S 1^{\circ}$ e $2^{\circ}$ do art. $23:{ }^{13}$ a legitimação fundiária é instituto que se aplica a ambas as modalidades de Reurb.

Quando o intérprete propõe uma norma (produto da interpretação do texto) diversa daquela que decorre do seu sentido literal (ou que não encontra legitimação em razão de dificuldades inerentes ao uso da linguagem), a atividade não é mais de interpretação e sim de criação do direito. Logo, essa proposição afronta o princípio do Estado Democrático que pressupõe a separação das funções de legislar e de julgar. 
Por conseguinte, a técnica de interpretação conforme a constituição (parágrafo único do art. 28 da Lei 9.868/1999) não pode ser empregada, pois é utilizada para salvar o ato normativo infraconstitucional como um todo da declaração de inconstitucionalidade, desde que seja possível compatibilizar texto e interpretação. A interpretação conforme a constituição encontra óbice nos limites semânticos do texto ou na moldura que é fornecida pelo legislador através do texto, ${ }^{14}$ resultando a existência de limites objetivos ao intérprete.

Somente quando uma regra admite duas ou mais interpretações será juridicamente viável que os tribunais definam justificadamente a que melhor se compatibilize com a Constituição para fins de coerência do ordenamento jurídico. Esse não é o caso da hipótese controvertida.

Outra categoria que deve ser referida quando se fala de interpretação e aplicação das regras no âmbito da jurisdição constitucional é a inconstitucionalidade parcial sem redução de texto (também prevista no parágrafo único do art. 28 da Lei 9.868/1999).

$\mathrm{Na}$ declaração de inconstitucionalidade parcial sem redução de texto não se questiona a constitucionalidade da lei ou da regra como um todo, nem se afastam alguns sentidos interpretativos da norma não condizentes com a Constituição. Trata-se de redução de parte da incidência da norma à luz dos eventos ou destinatários por ela abrangidos. Em vez de uma técnica de interpretação, ela pode ser considerada o produto final de um julgamento abstrato de constitucionalidade, e o motivo de sua utilização é meramente redacional, pois "a eliminação de parte do dispositivo afetaria também a parte constitucional, surgindo uma lacuna sem justificativa substancial." (DIMOULIS; LUNARDI, 2014, p. 418).

Enquanto a técnica de interpretação conforme a constituição atua no domínio da interpretação da lei, a inconstitucionalidade sem redução (ou modificação) de texto "localiza-se no âmbito da aplicação, pois pretende excluir alguns casos específicos da aplicação da lei." (SILVA, 2006, p. 201). Em outros termos: considera-se inconstitucional "apenas determinada hipótese de aplicação da lei, sem proceder à alteração do seu programa normativo." (MENDES, 2010, p. 1.425).

A partir de tal perspectiva jurídica, caso mantida a constitucionalidade do instituto ou instrumento da legitimação fundiária, impõe-se que o Supremo Tribunal Federal avance no exame da matéria e declare a nulidade parcial sem redução de texto para fins de exclusão da Reurb-E do escopo normativo do art. 23 da Lei 13.465/2017, mantendo-se, portanto, sua aplicabilidade exclusiva para a Regularização Fundiária Urbana Social - Reurb-S.

Do contrário, a regra do art. 23, além de permitir a grilagem de unidades imobiliárias urbanas, será inconstitucional também por afrontar ao princípio da isonomia, que pressupõe tratamento igualitário para situações análogas ou desigualdade em situações de desigualdade. Em realidade, a regra, em sua normatividade atual, apenas reforça a desigualdade social em nosso país.

\section{CONSIDERAÇÕES FINAIS}

A Medida Provisória 759 , de dezembro de 2016 , convertida na Lei 13.465 , de julho de 2017, acarretou inúmeras novidades no âmbito de atuação do direito urbanístico, em es- 
pecial no tocante à tentativa de regularizar concretamente os imóveis urbanos em situação irregular. Algumas das disposições ensejaram controvérsia no tocante aos seus objetivos e também quanto à constitucionalidade, tanto que foram ajuizadas ações declaratórias de inconstitucionalidades pendentes de julgamento pelo Supremo Tribunal Federal.

O instrumento da legitimação fundiária possui um objetivo nobre, mas também um grande potencial para gerar situações de perplexidade, sobretudo porque altera dogmas do direito urbanístico referentes à propriedade e a seu modo de aquisição. A maneira como se encontra disciplinado é inconstitucional porque, além de afrontar ao princípio da isonomia por impor restrições à aplicação do instrumento apenas à população de baixa renda (os verdadeiros destinatários da regularização fundiária urbana), expressa um significativo retrocesso na política de planejamento e desenvolvimento urbano com ênfase na função social das cidades. Além disso, possibilita inúmeros desvios de finalidade e outras práticas ilegais que vulneram a sociedade brasileira em geral e a população de baixa renda em especial.

Caso mantido o instrumento da legitimação fundiária no sistema jurídico nacional sob a provável justificativa de que é o único meio adequado para fins de regularização fundiária urbana de situações informais consolidadas, impõe-se que o Supremo Tribunal aplique a técnica da declaração de inconstitucionalidade parcial sem redução de texto para fins de afastar a sua aplicação para a modalidade da Reurb-E, mantendo-o exclusivamente para a Reurb-S, inclusive com os condicionantes previstos.

\section{NOTAS}

1. O direito de laje foi disciplinado como um novo direito real autônomo no art. 1.225 do CC/02 e regulado no art. 1.510-A do mesmo diploma legal. Possui relativa correspondência jurídica nos ordenamentos jurídicos da Itália e da Suíça (direito de mais elevação ou direito de sobre-edificação), embora encontre maior correspondência com a disciplina do art. 1.526 do Código Civil português. Não se confunde com a propriedade plena, tampouco com o direito de superfície, situando-se em uma posição intermediária que confere ao titular direito de propriedade quanto a pavimentos imobiliários autônomos. Sua principal função e, assim, seu mérito é regular e amparar direitos decorrentes de situações informais muito comuns na população de baixa renda (QUEIROZ; BACHA, 2018, p. 17-18 e 27). Assim, o direito de laje, "como direito real, na modalidade de direito real sobre coisa alheia de gozo ou fruição, permite o surgimento de uma propriedade resolúvel, que pode ser contratada por prazo determinado ou indeterminado, cuja resolução pode se dar mediante o termo ou a condição." (LIMA, 2017, p. 494).

2. A Lei $13.465 / 2017$ dispõe sobre inúmeros temas relacionados à propriedade e posse (urbana e rural) de imóveis (públicos e particulares), como usucapião extrajudicial, viabilidade da instituição de condomínio de lotes, criação do condomínio urbano simples, possibilidade de loteamento de acesso controlado e instituição do Código Nacional de Matrícula de imóveis. Também regulou aspectos concernentes ao programa Minha Casa, Minha Vida, ou seja, suas disposições alteraram disposições de direito urbanístico, civil, administrativo, ambiental, processual civil, agrário e registral. Por isso foram alterados diversos diplomas, como a Lei $n^{\circ}$ 8.629/1993 (Reforma agrária); Lei no 11.952/2009 (Regularização fundiária em terras da União, no âmbito da Amazônia Legal); Lei de Registros públicos; Código Civil; Código de Processo Civil; Programa Minha Casa, Minha Vida; Lei no 9.514/1997 (SFI); Lei nº 6.766/1979 (Parcelamento do Solo Urbano); Código Florestal; Lei no 9.636/1998 (Alienação de bens imóveis da União); MP n² 2.220/2001 (Concessão de uso especial); Decreto-Lei n 9.760/1946 (Bens imóveis da União); e Decreto-Lei n 3.365/1941 (Desapropriação).

3. A ADI 5.771, ajuizada pelo Procurador-geral da República, Rodrigo Janot, após o recebimento de 
representações apresentadas por 61 entidades, tem como pedido declaração de inconstitucionalidade da totalidade da Lei 13.465/2017. Conforme a inicial, a Lei apresenta vícios formais e materiais, e a sua manutenção no sistema jurídico representa graves retrocessos em matéria de direitos fundamentais. A ADI 5.787, elaborada pelo Partido dos Trabalhadores - PT, apresenta requerimento de inconstitucionalidade não da totalidade da Lei, mas de inúmeras disposições, também por vícios formais e materiais. Por fim, a ADI 5.883, proposta pelo Instituto de Arquitetos do Brasil - IAB, com requerimento, ao final, de declaração de inconstitucionalidade da Regularização Fundiária Urbana - Reurb (disciplinada no Título II da Lei - arts. $9^{\circ}$ a 82 , e tratada também nos arts. 83 e 84,87 a 90, e 98; o $\S 2^{\circ}$ do art. 11-C, da Lei n. 9.636, de 1998, incluído pelo art. 93 da Lei; e o $\S 5^{\circ}$ do art. $1^{\circ}$, do Decreto-Lei n. 1.876, de 1981, incluído pelo art. 95 da Lei).

4. Registra-se o disposto no $\S^{\circ}$ do art. 14: "O requerimento de instauração da Reurb por proprietários de terreno, loteadores e incorporadores que tenham dado causa à formação de núcleos urbanos informais, ou os seus sucessores, não os eximirá de responsabilidades administrativa, civil ou criminal."

5. Outra definição disposta no art. 11, VII, da legislação referida é a de que a legitimação fundiária é "o mecanismo de reconhecimento da aquisição originária do direito real de propriedade sobre unidade imobiliária objeto da Reurb."

6. Núcleo urbano informal consolidado foi definido pelo legislador (art. 11, III) como "aquele de difícil reversão, considerados o tempo da ocupação, a natureza das edificações, a localização das vias de circulação e a presença de equipamentos públicos, entre outras circunstâncias a serem avaliadas pelo Município."

7. Nesse contexto, "não descaracteriza o caráter expropriatório o fato de o bem ser destinado a outro particular, pois o desposo administrativo e compulsório é o ponto essencial". Assim, "havendo um ato administrativo de outorga da legitimação fundiária, por iniciativa discricionária da administração pública, desposando o titular registral do bem da propriedade em favor de outro particular e sem indenização, tem-se claramente os contornos da desapropriação indireta." (REIS; LELIS, 2018, p. 54).

8. Nesse sentido também se manifesta Godoy (2017, p. 466-467), que enfatiza não se tratar de usucapião ou de desapropriação, além de registrar que, apesar da discricionariedade do ato, o Poder Público sempre deve pautar seu agir com fundamento no interesse público.

9. Art. 23, $\S 4^{\circ}$. Na Reurb-S de imóveis públicos, a União, os Estados, o Distrito Federal e os Municípios, e as suas entidades vinculadas, quando titulares do domínio, ficam autorizados a reconhecer o direito de propriedade aos ocupantes do núcleo urbano informal regularizado por meio da legitimação fundiária.

10. Art. 71. Para fins da Reurb, ficam dispensadas a desafetação e as exigências previstas no inciso I do caput do art. 17 da Lei no 8.666, de 21 de junho de 1993.

11. A questão da pós-titulação é essencial por se consubstanciar numa fase atrelada ao processo de regularização fundiária, na medida em que a regularização, sobretudo a de interesse social, não se encerra com a entrega do título, impondo-se a obrigação de o Poder Público fornecer os serviços públicos essenciais para concretizar totalmente o direito à moradia, bem como verificar o comportamento dos beneficiários e do próprio mercado imobiliário após a contemplação, aspectos sociais não tratados na legislação e que resultam em uma importante lacuna normativa com consequências práticas relevantes. (CARMONA et al, 2018, p. 39-40).

12. Esse efeito liberatório geral, notadamente na Reurb-E, também é questionado: "Quanto ao efeito liberatório, aparentemente o legislador pretendeu desonerar o adquirente de penhoras, ônus fiscais ou direitos de garantia pendente sobre o imóvel, pelo que o dispositivo deve ser interpretado com cautela. Não nos parece razoável que direitos reais sobre coisa alheia como servidões, restrições edilícias e servidões administrativas, que nada têm a ver com tais finalidades, sejam alcançados por tal efeito liberatório." (REIS; LELIS, 2018, p. 50).

13. Art. 23. A legitimação fundiária constitui forma originária de aquisição do direito real de propriedade conferido por ato do Poder Público, exclusivamente no âmbito da Reurb, àquele que detiver em área 
pública ou possuir em área privada, como sua, unidade imobiliária com destinação urbana, integrante de núcleo urbano informal consolidado existente em 22 de dezembro de 2016. $\S$ 10 $^{\mathbf{0}}$ Apenas na Reurb-S, a legitimação fundiária será concedida ao beneficiário, desde que atendidas as seguintes condições: I - o beneficiário não seja concessionário, foreiro ou proprietário de imóvel urbano ou rural; II - o beneficiário não tenha sido contemplado com legitimação de posse ou fundiária de imóvel urbano com a mesma finalidade, ainda que situado em núcleo urbano distinto; e III - em caso de imóvel urbano com finalidade não residencial, seja reconhecido pelo Poder Público o interesse público de sua ocupação. $\S 2^{\circ}$ Por meio da legitimação fundiária, em qualquer das modalidades da Reurb, o ocupante adquire a unidade imobiliária com destinação urbana livre e desembaraçada de quaisquer ônus, direitos reais, gravames ou inscrições, eventualmente existentes em sua matrícula de origem, exceto quando disserem respeito ao próprio legitimado. $\S 3^{\circ}[\ldots]$. (Grifos não constam no original).

14. "Quando a letra não permite certa interpretação e se ela for considerada a única que conciliaria a norma com a Constituição, deve ser declarada a inconstitucionalidade da norma (ou a omissão inconstitucional). Temos aqui o limite textual imposto à interpretação conforme." (DIMOULIS; LUNARDI, 2014, p. 415).

\section{REFERÊNCIAS}

ALFONSIN, Betânia de Moraes. O significado do Estatuto da Cidade para os processos de regularização fundiária no Brasil. In: ROLNIK, Raquel et al. Regularização fundiária sustentável - conceitos e diretrizes. Brasília: Ministério das Cidades, 2007, p. 68-98.

CARMONA, Paulo Afonso Cavichioli et al. Análise social da pós-titulação na regularização fundiária de interesse social brasileira. Revista Magister de Direito Ambiental e Urbanístico, Porto Alegre, v. 13, n. 75, p. 32-46, dez. 2017/jan. 2018.

GODOY, Fernando Henrique Rovere de. A regularização fundiária urbana de acordo com a Lei 13.465/2017: uma tentativa de inserir a cidade informal dentro da cidade formal. Revista de Direito Imobiliário, São Paulo, v. 40, n. 83, p. 455-476, jul./dez. 2017.

LIMA, Frederico Henrique Viegas de. Direito de laje: características e estrutura. Revista de Direito Imobiliário, São Paulo, v. 40, n. 83, p. 477-494, jul./dez. 2017.

LUNARDI, Soraya Regina Gasparetto; DIMOULIS, Dimitri. Interpretação conforme a Constituição e declaração de inconstitucionalidade sem redução de texto. Problemas da aplicação judicial do direito constitucional. Revista Brasileira de Estudos Constitucionais: RBEC, Belo Horizonte, v. 8, n. 29, p. 403-425, maio/ago. 2014.

MAFFINI, Rafael Da Cás. A Lei 13.465/2017 (Lei de Regularização Fundiária Rural e Urbana) e o Direito Administrativo. Revista de Direito Imobiliário, São Paulo, v. 40, n. 83, p. 553-570, jul./dez. 2017.

MENDES, Gilmar Ferreira. Curso de direito constitucional / Gilmar Ferreira Mendes, Inocêncio Mártires Coelho, Paulo Gustavo Gonet Branco. - 5. ed. ver. e atual. - São Paulo: Saraiva, 2010.

QUEIROZ, Odete Novais Carneiro; BACHA, Ahmad Jamal Ahmad el. Direito de laje. Revista Magister de Direito Ambiental e Urbanístico, Porto Alegre, v. 13, n. 76, p. 5-28, fev./mar. 2018.

REIS, Eduardo Moreira; LELIS, Natália. Legitimação fundiária - Natureza jurídica e aplicabilidade prática. Revista Magister de Direito Ambiental e Urbanístico, Porto Alegre, v. 13, n. 75, p. 47-63, dez. 2017/jan. 2018. 
SCHEID, Cintia Maria. O princípio da função social da propriedade e sua repercussão na evolução da regularização fundiária urbana no ordenamento jurídico brasileiro. Revista de Direito Imobiliário, São Paulo, v. 40, n. 83, p. 423-454, jul./dez. 2017.

SILVA, Virgílio Afonso da. Interpretação conforme a Constituição: entre a trivialidade e a centralização judicial. Revista Direito GV, São Paulo, v. 2, n. 1, p. 191-210, jan/jun. 2006.

Recebido em: 06/03/2019

Aceito em: 06/08/2019 